Lisiński P. Physical therapy in nerve injuries. Issue Rehabil. Orthop. Neurophysiol. Sport Promot. 2017; 18: 49-57. DOI: 10.19271/IRONS-00034-2017-18

\section{PHYSICAL THERAPY IN NERVE INJURIES}

\section{Przemysław Lisiński}

Clinic for Rehabilitation, University of Medical Sciences, Poznań, Poland

\section{SUMMARY}

Nerve injuries are commonly observed in clinical practice both in surgery and on rehabilitation wards. Most often effects of nerve injuries are muscle weakness and pain sensation. When mentioned clinical symptoms occur, electrotherapeutic procedures are commonly used not only for pain treatment but also for strengthening of weak muscles to restore and improve transmission of impulses via motor or sensory fibers of damaged nerves. However, their efficiency is still disputed by many authorities and practitioners. Aim of this study is a summary, supported by literature recommendations, of contemporary theory and practice of electrotherapy to other than physiotherapy and rehabilitation specialists.

Keywords: upper extremity, nerve injury, electrotherapy

Date received: 17th February 2017

Date accepted: 22nd February 2017

\section{Introduction}

Nerve injuries are a serious health problem and result in longlasting disabilities. There is little information about their frequency of occurrence and good practice in treatment (Scholz et al. 2009). Upper extremity nerve injuries can occur during sport or occupational activity. This pathology seems to be real when pain, weakness, or paresthesia appears in the absence of other tissues in upper extremity injuries (Neal and Fields 2010). Other reason for described pathology is the perioperative nerve traction. Particularly patients undergoing shoulder or
FIZYKOTERAPIA W USZKODZENIACH NERWóW

Przemysław Lisiński

Klinika Rehabilitacji Uniwersytet Medyczny w Poznaniu

\section{STRESZCZENIE}

Uszkodzenia nerwów są powszechnie obserwowane na oddziałach chirurgicznych jak i rehabilitacyjnych. Najczęstszymi objawami są w tych przypadkach niedowłady mięśni i ból. Gdy wspomniane objawy występują stosuje się najczęściej elektroterapię, aby przywrócić lub poprawić przewodnictwo we włóknach ruchowych lub czuciowych nerwów. Jednakże efektywność tych metod jest ciągle kwestionowana przez wiele autorytetów i lekarzy praktyków. Celem tej pracy jest sumaryczne, poparte aktualnym piśmiennictwem, przybliżenie teorii i praktyki dotyczącej elektroterapii, innym niż fizjoterapeuci i lekarze specjalistom.

Słowa kluczowe: kończyna górna, uszkodzenie nerwu, elektroterapia

Data otrzymania: 17 luty 2017

Data zaakceptowania: 22 luty 2017

elbow surgical interventions are in a group of risk (Plastaras et al. 2014). The incidence of nerve injury coexisting with upper limb trauma occurs approximately at $1.64 \%$. Most often nerve injury is connected with a crush injury (Taylor et al. 2008). In most cases initial treatment should be nonsurgical. One of the most common conservative procedures used at the beginning of the treatment is electrotherapy. Theoretically, when weakness, pain, and/or paresthesia appear, voltage-dependent conductive properties of nerves allow to apply the chosen 
electrotherapeutic procedures not only for pain or paresthesia treatment but also for strengthening of weak muscles to restore and improve transmission of impulses via motor or sensory fibers of damaged nerves. However, their efficiency is still questionable by many authorities and practitioners.

\section{Aim}

Aim of this study is, supported by literature recommendations, summary of contemporary theory and practice of electrotherapy to other than physiotherapy and rehabilitation specialists.

\section{Patients and method}

Research of MEDLINE database was chosen as a method. Keywords in following order were entered: upper extremity, nerve injury, and electrotherapy. Only researches from 2000 to 2016 were taken under consideration.

\section{Results}

Finally 33 papers have been identified. Treatment of pain was described in 15 papers, procedures of muscle electrostimulation resulting in strength improvement were presented in 9 papers, and studies of nerve repair neural transmission were described in 9 papers. Generally, effects of electrotherapy in treatment of upper limb nerve injuries are described in these three categories.

\section{Pain modulation}

Electrotherapy is mentioned as one of the oldest methods of pain treatment. History of this method, effectively applied by different nations and cultures in past centuries, started in ancient times. Our medical antecedents probably accommodated for medical practice the natural, biological phenomena. Theoretical basis for direct stimulation of peripheral nerves is the theory of the "gate control" by Melzack and Wall from 1965 . Since then, this idea has been applied to the treatment of different painful conditions (Henderson 2008). Effectiveness of other electrotherapeutic modalities (diathermy, iontophoresis or transcutaneous electrical nerve stimulation), which aim to reduce pain, are based on an increase of total electrical energy into the body of a patient. Their analgesic, physiological effect is explained generally by modification of the nociceptors function, dorsal root ganglia cells and spinal ascending tracts excitability (Page et al. 2014). Only few classic electrotherapeutic modalities are described in current literature as effective in the case of upper extremity pain occurrence. Most often transcutaneous electrostimulation (TENS) is used in treatment of pain in patients with rotator cuff injuries or carpal tunnel syndrome (Page et al. 2016). Parameters of TENS application are often individual-dependent because of the variety in threshold excitability of proprioceptors and nociceptors in an area of pain. However, optimal output parameters should be: $100 \mathrm{~Hz}$ frequency, $80 \mathrm{~ms}$ width of single pulse and a duration of stimulation session for 30 minutes (Casale et al. 2013). Location of electrodes in patient with pain originated from rotator cuff injury is presented in Figure 1.

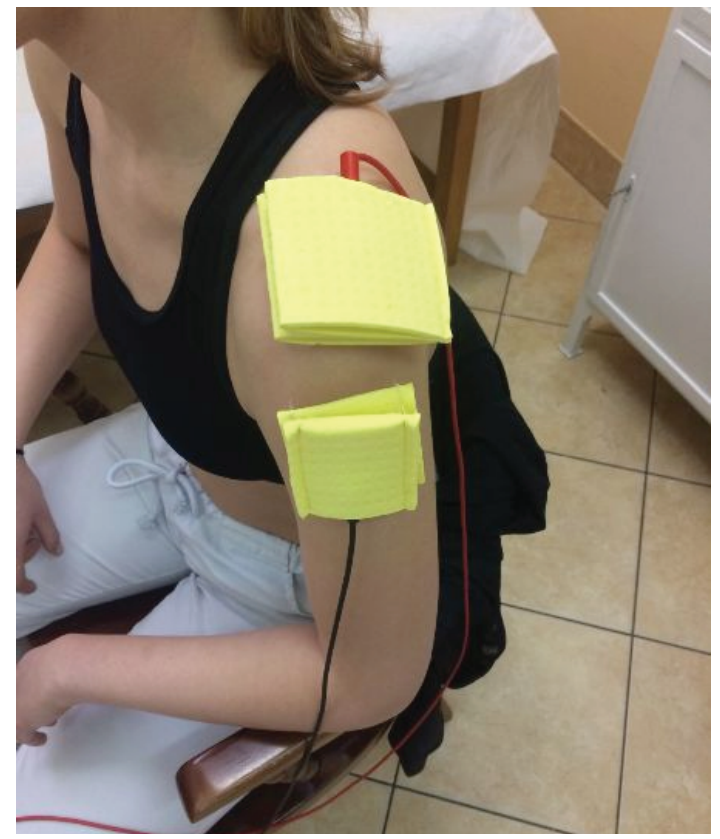

Figure 1. TENS procedure in the case of patient with rotator cuff injury.

50 Issues of Rehabilitation, Orthopaedics, Neurophysiology and Sport Promotion - IRONS 
We can very often observe in clinical practice that myofascial pain syndrome in neck and shoulder region which coexists with pain arising from rotator cuff injury. In this case a variation of classic TENS, a method called simply pulsed neuromuscular stimulus (PENS), applied in trigger points treatment is equally effective (Iodice et al. 2016). Based on my experience, I would like to recommend the interferential current as a safe electrotherapeutic option for the treatment of pain in rotator cuff injuries (see Figure 2). The neural fibers transmitting pain sensation are blocked, due to their position, relative to the electrodes, the modulation frequency and the strength of the stimulus (Agharezaee and Mahnam 2015). During the interferential current therapy I have noticed less incidences of complications like arrhythmia or hypertension which are sometimes observed when the TENS near chest is used. Additionally, the interferential current is recommended in treatment of pain connected with the carpal tunnel syndrome (Koca et al. 2014).

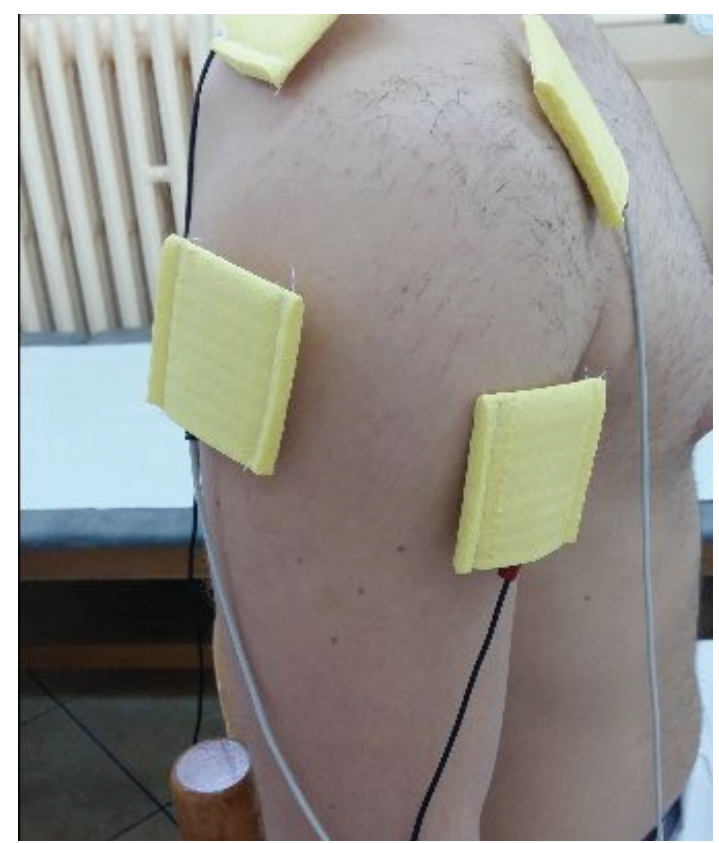

Figure 2. Interferential current therapy in the case of rotator cuff injury.

Electroacupuncture is another very interesting application of electrotherapy which was explored last decade. Although this method is mostly used in deactivation of active trigger points in patients with myofascial pain syndrome, some instances of upper limb nerve injuries treatment resulting in pain decreasing are mentioned in the literature. Its mechanism of action is explained by regulation of COX-2 expression in nociceptive sites leading to decrease of inflammatory edema and hyperalgesia. Further, commonly known term "functional electrostimulation (FES)" is routinely used for activation of paralyzed muscles in patients with spasticity after stroke, cerebral and spinal cord injuries. Application of FES in peripheral pain treatment is described as an effective method only once, in the case of regional pain syndrome as a consequence of compound upper extermity trauma (Planitzer et al. 2014). This serious complication can be successfully treated by electrical neuromodulation of the dorsal root ganglia (DRG), decreasing intensity of all sensorimotor, vascular and trophic changes (Van Buyten et al. 2015). New possibilities of improving pain treatment in cases of upper extermity nerve injuries are connected to application of advanced technologies. For example, motor cortex stimulation (MCS) seems to be effective in treatment of chronic neuropathic pain in upper extremity (Fagundes-Pereyra et al. 2010). Its anti-pain actions is explained by direct alteration of brain activity. The only efficient method of chronic pain treatment found in the literature is the transcranial direct current stimulation (tDCS) with short-term effects, so the further investigations are necessary (O'Connell et al. 2011). Implanted periodically or permanently peripheral nerve stimulator is also the "future" of treatment in chronic, neuropathic pain associated with brachial plexus injuries (Stevanato et al. 2014).

\section{Muscle strenght Improvement}

Electrostimulation with different parameters like a shape of singular pulse, its 
width, frequency of stimulation and its duration were analyzed through prism of their effectiveness in a treatment of muscle's weakness in past decades. At this time, the attention of researches is still turned to optimization of parameters of electrostimulation to achieve the strongest contraction without pain sensation and fatigue of stimulated muscle. One of the more interesting conceptions in this area is using the multi-contact electrodes for stimulation which allows for activation of different motoneurons of single peripheral nerve at the same time resulting in excitation of corresponding populations of motor units to produce strong, selective muscles' contractions (Fisher et al. 2013). Another solution serving the stated aim is the improvement of muscle activation through biofeedback. Commands and feedback signals are extracted from biopotentials recorded from muscles (EMG), nerves (ENG) or the brain (EEG). This model of electrostimulation seems to be the most natural and the least harmful but further investigations are needed (Sinkjaer et al. 2003; Baldwin et al. 2006). One of the most common complications observed after electrostimulations of muscles is their fatigue. According to some observations (Dreibati et al. 2011), the efficiency of electrical stimulation aiming to increase the muscle strength without corresponding fatigue seems to be possible to achieve with smaller number of contractions per one session with a higher level of force production, resulting in even more than $60 \%$ of maximal voluntary contraction. Additionally, better results are achieved when the asynchronous low-pulse-rate electrostimulation is applied (Maneski et al. 2013). Technical progress allows introducing to clinical practice new devices and technologies. Preliminary reports indicate that anodal transcranial direct current stimulation (tDCS) applied over the primary motor cortex (upgrade of the synaptic strength) can significantly improve the strength of grip (Saimpont et al. 2016; Karok and Witney 2013).
Strengthening of muscles may be a result of using the low-amplitude transcutaneous electrical peripheral nerve stimulation (TENS). This procedure by modulation of cortical and corticospinal excitability can enforce the final motor output resulting for example in improvement of grip strength or activity of trapezius muscle (Tataroglu et al. 2011).

\section{Nerves' regeneration}

Beside of pain and muscle weakness, the third very important symptom of nerve injury is parenthesis. Pathology, initially located in a site of injury secondarily evokes the degenerative changes in conductive elements of spinal cord (apoptosis). It was proved recently that electroacupuncture applied with the high-intensity and low-frequency, promotes functional motor nerve repair probably by increasing the secretion of neurotrophic factors in CNS ( $\mathrm{He}$ et al. 2015). It seems to be real since the same determinant explains effectiveness of electrostimulation in enhanced sensory reinnervation after complete digital nerve transection (Wong et al. 2015). Positive effect of stimulation was observed when the biphasic electric current was applied (Kim et al. 2011). Axonal regeneration in humans (ENG studies) was proved when longlasting (1 hour) bipolar electrostimulation was applied with low frequency (20 Hz; bipolar) (Gordon et al. 2010). It should be reminded that electrostimulation diminishes misdirection of regenerating motor axons caused by end-organ deprivation (Gordon and English 2016). Effectiveness of electroacupuncture with direct current as a method for increasing the ulnar and medial nerves regeneration was also recently presented (Xia et al. 2013; Tang et al. 2016). Location of needles is presented in Figure 3.

52 Issues of Rehabilitation, Orthopaedics, Neurophysiology and Sport Promotion - IRONS 


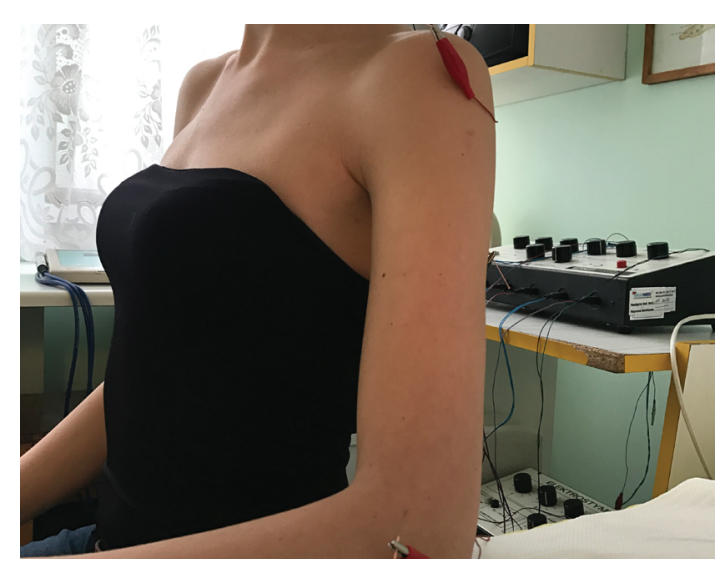

Figure 3. Location of electroacupuncture needles directed for ulnar nerve regeneration.

\section{Discussion}

Different electrotherapy applications such as: direct current (DC), electrostimulations (altering current; AC), interferential current (IC), functional electrostimulations (FES) are used commonly in patients with nerve injuries treated conservatively. According to the rules of Polish Concept of Rehabilitation, the electrotherapy is only a part of complex treatment in this situation. It should be applicable on a par with kinesiotherapy. In other countries the electrotherapy procedures are used alone without kinesiotherapeutic support. In this situation, the estimation of electrotherapeutic efficiency in clinical categories is difficult and very often these methods of treatment are rejected. A few decades ago, in 1970' and 1980', many papers were published and efficiency of many kinds of electrotherapy was postulated based on clinical observations. In recent years few interesting papers in the area of electrotherapy were published and their results were often proved by MRI images or neurophysiological studies, although clinical proofs still dominate.

\section{Conclusion}

At the beginning of XXI century, according to concept of Evidence Based Medicine, we are creating a new approach to validation of electrotherapy. It is possible because new technologies and diagnostic tools like fRMI, EMG and ENG are available. 


\section{REFERENCES}

Agharezaee, M., Mahnam, A. (2015) "A computational study to evaluate the activation pattern of nerve fibers in response to interferential currents stimulation". Med Biol Eng Comput, 53(8),pp. 713-20.

Baldwin, E.R., Klakowicz, P.M., Collins, D.F. (2006) "Influence of stimulus pulse width on $M$-waves, $H$-reflexes and torque during tetanic low-intensity neuromuscular stimulation". J Appl Physiol (1985), 101(1), pp. 228-40.

Casale, R., Damiani, C., Maestri, R., Wells, C.D. (2013) "Pain and electrophysiological parameters are improved by combined 830 1064 high-intensity LASER in symptomatic carpal tunnel syndrome versus Transcutaneous Electrical Nerve Stimulation. A randomized controlled study". Eur J Phys Rehabil Med, 49(2), pp. 205-11.

Dreibati, B., Lavet, C., Pinti, A., Poumarat, G. (2010) "Influence of electrical stimulation frequency on skeletal muscle force and fatigue". Ann Phys Rehabil Med, 53, pp. 266-277.

Fagundes-Pereyra, W.J., Teixeira, M.J., Reyns, N., Touzet, G., Dantas, S., Laureau, E., Blond, S. (2010) "Motor cortex electric stimulation for the treatment of neuropathic pain". Arq Neuropsiquiatr, 68(6), pp. 923-928.

Fisher, L.E., Tyler, D.J., Triolo, R.J. (2013) "Optimization of selective stimulation parameters for multi-contact electrodes". J Neuroeng Rehabil, 10:p. 25.

Gordon, T., Chan, K.M., Sulaiman, O.A., Udina, E., Amirjani, N., Brushart, T.M. (2009) "Accelerating axon growth to overcome limitations in functional recovery after peripheral nerve injury". Neurosurgery, 65(4), pp. A132-144.

Gordon, T., English, A.W. (2016) "Strategies to promote peripheral nerve regeneration: electrical stimulation and/or exercise". Eur J Neurosci, 43(3), pp. 336-350.

He, G.H., Ruan, J.W., Zeng, Y.S., Zhou, X., Ding, Y., Zhou, G.H. (2015) "Improvement in acupoint selection for acupuncture of nerves surrounding the injury site: electro-acupuncture with Governor vessel with local meridian acupoints". Neural Regen Res, 10(1), pp. 128-35.

Henderson J.M. (2008) "Peripheral nerve stimulation for chronic pain". Curr Pain Headache Rep, 12(1), pp. 28-31.

Iodice, P., Lessiani, G., Franzone, G., Pezzulo, G. (2016) "Efficacy of pulsed low-intensity electric neuromuscular stimulation in reducing pain and disability in patients with myofascial syndrome". J Biol Regul Homeost Agents, 30(2), pp. 615-620.

Karok, S., Witney, A.G. (2013) "Enhanced Motor Learning Following Task-Concurrent Dual Transcranial Direct Current Stimulation". PLoS One, 8(12), p. e85693.

Kim, I.S., Song, Y.M., Cho, T.H., Pan, H., Lee, T.H., Kim, S.J., Hwang, S.J. (2011) "Biphasic electrical targeting plays a significant role in schwann cell activation". Tissue Eng Part A, 17(9-10), pp. 1327-1340.

Koca, I., Boyaci, A., Tutoglu, A., Ucar, M., Kocaturk, O. (2014) "Assessment of the effectiveness of interferential current therapy and TENS in the management of carpal tunnel syndrome". a randomized controlled study Rheumatol Int. 34(12), pp. 1639-45. Maneski, L.Z., Malešević, N.M., Savić, A.M., Keller, T., Popović, D.B. (2013) "Distributed low-frequency functional electrical stimulation delays muscle fatigue compared to conventional stimulation" Muscle Nerve, 48 (6), pp. 930-937.

Neal, S., Fields, K.B. (2010) "Peripheral nerve entrapment and injury in the upper extremity". Am Fam Physician, 81(2), pp. 147-55.

O'Connell, N.E., Wand, B.M., Marston, L., Spencer, S., Desouza, L.H. (2011) "Non-invasive brain stimulation techniques for chronic pain. A report of a Cochrane systematic review and meta-analysis". Eur J Phys Rehabil Med. 47, pp. 309-326.

Page, M.J., Green, S., Kramer, S., Johnston, R.V., McBain, B., Buchbinder, R. (2014) "Electrotherapy modalities for adhesive 
capsulitis (frozen shoulder)". Cochrane Database Syst Rev, 1(10),p. CD011324.

Page, M.J., Green., Mrocki, M.A., Surace, S.J., Deitch, J., McBain, B., Lyttle, N., Buchbinder, R. (2016) "Electrotherapy modalities for rotator cuff disease". Cochrane Database Syst Rev. 10(6), p. CD012225. Planitzer, U., Steinke, H., Meixensberger, J., Bechmann, I., Hammer, N., Winkler, D. (2014) "Median nerve fascicular anatomy as a basis for distal neural prostheses". Ann Anat, 196(2-3), pp. 144-149.

Plastaras, C.T., Chhatre, A., Kotcharian, A.S. (2014) "Perioperative upper extremity peripheral nerve traction injuries". Orthop Clin North Am, 45(1), pp. 47-53.

Saimpont, A., Mercier, C., Malouin, F., Guillot, A., Collet, C., Doyon, J., Jackson, P.L. (2016) "Anodal transcranial direct current stimulation enhances the effects of motor imagery training in a finger tapping task". Eur J Neurosci, 43(1), pp. 113-119.

Scholz, T., Krichevsky, A., Sumarto, A., Jaffurs, D., Wirth, G.A., Paydar, K., Evans, G.R. (2009) "Peripheral nerve injuries: an international survey of current treatments and future perspectives". J Reconstr Microsurg, 25(6), pp. 339-344.

Sinkjaer, T., Haugland, M., Inmann, A., Hansen, M., Nielsen, K.D. (2003) "Biopotentials as command and feedback signals in functional electrical stimulation systems". Med Eng Phys, 25(1), pp. 29-40.

Stevanato, G., Devigili, G., Eleopra, R., Fontana, P., Lettieri, C., Baracco, C., Guida, F., Rinaldo, S., Bevilacqua, M., (2014) "Chronic post-traumatic neuropathic pain of brachial plexus and upper limb: a new technique of peripheral nerve stimulation". Neurosurg Rev. 37(3), pp. 473-479.

Tang, Y.J., Wu, M.H., Tai, C.J. (2016) "Direct electrical stimulation on the injured ulnar nerve using acupuncture needles combined with rehabilitation accelerates nerve regeneration and functional recovery-A case report". Complement Ther Med, 24, pp. 103-107. Tataroglu, C., Kuçuk, F.K., Ozkul, A. (2011) "Upper and lower extremity proprioceptive inputs modulate EMG activity of the trapezius". J Electromyogr Kinesiol, 21, pp. 77-81. Taylor, C.A., Braza, D., Rice, J.B., Dillingham, T. (2008). "The incidence of peripheral nerve injury in extremity trauma". Am J Phys Med Rehabil, 87(5), pp. 381-385.

Van Buyten, J.P., Smet, I., Liem, L., Russo, M., Huygen, F. (2015) "Stimulation of Dorsal Root Ganglia for the Management of Complex Regional Pain Syndrome: A Prospective Case Series". Pain Pract, 15(3), pp. 208-216.

Wong, J.N., Olson, J.L., Morhart, M.J., Chan, K.M. (2015) "Electrical stimulation enhances sensory recovery: a randomized controlled trial". Ann Neurol, 77(6), pp. 996-1006.

Xia, Q., Liu, X.W., Wang, X.L. (2013) "Efficacy observation of carpal tunnel syndrome treated with electroacupuncture". Zhongguo Zhen Jiu, 33(8), pp. 700-702. 
Author reported no source of funding. Author declared no conflict of interest.

Author responsible for correspondence: Przemystaw Lisiński

Clinic for Rehabilitation

University of Medical Sciences,

Poznań, Poland

28 Czerwca 1956 Str., No 135/147

60-545 Poznań

Poland

plisinski@vp.pl
Autor nie zgłosił źródła finansowania.

Autor nie deklarował konfliktu interesów.

Autor odpowiedzialny za korespondencję:

Przemysław Lisiński

Klinika Rehabilitacji

Uniwersytet Medyczny w Poznaniu

ul. 28 Czerwca 1956, Nr 135/147

60-545 Poznań

plisinski@vp.pl 